\title{
ANALISIS PENENTUAN HARGA POKOK PRODUKSI DALAM MENENTUKAN HARGA JUAL PRODUK (STUDI EMPIRIS PADA UMKM DENDENG SAPI DI BANDA ACEH)
}

\author{
Ruthia Bahri*1, Rahmawaty ${ }^{* 2}$ \\ ${ }^{1,2}$ Program Studi Akuntansi Fakultas Ekonomi dan Bisnis Universitas Syiah Kuala \\ e-mail: ruthiabahri31@gmail.com ${ }^{* 1}$,rahmawaty@unsyiah.ac.id ${ }^{* 2}$
}

\begin{abstract}
The purpose of this study was to analyze the determination of cost of goods manufactured by using full costing and variable costing, approachment and to get the information about the difference of selling price between the one which is stated by MSMEs in beef jerky processing industry in Banda Aceh and the one which is the result based on cost plus pricing method. This type of research is descriptive analysis. Based on certain criterias, there are 3 MSMEs as the samples of the research. This research shows that the cost of production of the full costing method is greater than the variable costing method. Results of determining the selling price of products also shows that there is a difference between the selling price of the products specified MSMEs of beef jerky with a selling price obtained from cost plus pricing method.
\end{abstract}

Keywords: Sales Price of Products, Cost of Goods Manufactured, and Micro Small and Medium Enterprises (MSMEs) in beef jerky industry.

\section{Pendahuluan}

\section{Latar Belakang}

Usaha Mikro Kecil Menengah (UMKM) adalah industri yang merupakan sarana dalam meningkatkan kesejahteraan masyarakat terutama masyarakat daerah, UMKM juga disebut sebagai kegiatan yang sangat mendongkrak tingkat pengangguran dan mata pencaharian masyarakat kecil. Banda Aceh merupakan ibukota Provinsi Aceh, kota ini memiliki banyak penduduk serta hadirnya pendatang dari berbagai kabupaten. Pertumbuhan penduduk memicu adanya perbedaan permintaan dalam kebutuhan masingmasing. Keadaan ini dijadikan kesempatan oleh para pengusaha terutama para pelaku usaha UMKM. Statistik Banda Aceh 2015 membagi jumlah usaha mikro, kecil dan menengah kedalam beberapa sektor yaitu: (1) Perdagangan (2) Pertanian (3) Perikanan dan Kelautan (4) Industri Pengolahan serta (5) Aneka Jasa.

Jumlah UMKM di Banda Aceh saat ini memiliki peningkatan setiap tahunnya. Salah satunya yang paling banyak berkembang adalah di sektor industri pengolahan, baik itu UMKM tingkat mikro, kecil maupun menengah. Sebagian industri pengolahan makanan maupun pengolahan minuman sudah familiar dengan masyarakat, seperti industri pengolahan kopi yang sudah menjadi khas minuman Aceh serta dendeng sapi khas makanan Aceh dan buah tangan dari Aceh. Perdagangan dendeng sapi misalnya penjualan dendeng sapi sudah memasuki perdagangan nasional karena sudah melakukan penjualan ke kota lain seperti Kota Medan. Namun industri pengolahan dendeng sapi belum menghitungan harga pokok produksi dengan metode yang benar, padahal usaha ini seharusnya sudah melakukan perhitungan harga pokok produksi secara benar dan detail.

Masalah yang sering dihadapi oleh pengusaha UMKM bersifat multidimensi, artinya UMKM tersebut berada pada situasi dimana banyak permasalahan yang dihadapi UMKM tersebut. Salah satunya kesalahan yang sering dilakukan oleh pelaku usaha UMKM adalah menetapkan harga jual yang salah. Kesalahan ini sering terjadi karena adanya kesalahan dalam menghitung harga pokok produksi. Kesalahan ini akan berujung fataal yang akan memicu terjadinya kebangkrutan. Pelaku usaha diharapkan mampu mengkoordinasikan sumber daya yang dimiliki secara efektif dan efisien sehingga dapat membuat keputusan-keputusan yang diperlukan dalam mewujudkan tujuan perusahaan. Pelaku usaha diharapkan mampu mengkoordinasikan sumber daya 
yang dimiliki secara efektif dan efisien sehingga dapat membuat keputusan-keputusan yang diperlukan dalam mewujudkan tujuan perusahaan.

\section{Rumusan Masalah}

Rumusan masalah dalam penelitian ini berdasarkan latar belakang adalah:

1) Apakah UMKM dendeng sapi di Banda Aceh sudah melakukan penetapan harga pokok produksi.

2) Apa metode yang tepat dalam menetapkan harga jual produk yang ditentukan oleh UMKM dendeng sapi di Banda Aceh.

3) Apa metode penetapan harga pokok produksi yang tepat digunakan oleh UMKM dendeng sapi di Banda Aceh.

4) Bagaimana perbedaan antara tingkat penetapan harga jual yang telah ditetapkan selama ini dengan penetapan harga jual yang diperoleh dari penetapan harga pokok produksi.

\section{Tujuan Penelitian}

Berdasarkan rumusan masalah, maka yang menjadi tujuan penelitian ini adalah untuk mengetahui:

1) Untuk mengetahui apakah UMKM dendeng sapi di Banda Aceh melakukan penetapan harga pokok produksi.

2) Untuk mengetahui apa metode penetapan harga jual yang diterapkan oleh UMKM dendeng sapi di Banda Aceh.

3) Untuk mengetahui metode penetapan harga pokok produksi yang tepat digunakan oleh UMKM dendeng sapi di Banda Aceh

4) Untuk mengetahui perbedaan antara tingkat penetapan harga jual yang telah ditetapkan selama ini dengan penetapan harga jual yang diperoleh dari penetapan harga pokok produksi.

\section{Kajian Pustaka}

\section{Akuntansi Biaya}

Dunia dan Wasilah (2012:4) mendefiniskan akuntansi biaya sama dengan akuntansi manjemen namun lebih berfokus pada biaya yang dibutuhkan selama proses produksi berlangsung. Raiborn dan Kinney (2011:4) juga menjelaskan bahwa akuntansi biaya mengupas akuntansi keuangan dan akuntansi manajemen serta menyediakan informasi biaya dari suatu produk untuk kepentingan berbagai pihak, baik itu pihak eksternal maupun pihak internal.

\section{Biaya}

Biaya ialah suatu nilai yang dimanfaatkan atau dikorbankan guna mendapatkan barang dan jasa. Biaya yang dikorbankan bisa berupa biaya sekarang dan biaya yang akan terjadi di masa yang akan datang (Utami, Dwiatmanto, \& NP, 2016). Biaya adalah pengeluaran yang diukur dalam moneter yang telah dikeluarkan atau potensial akan dikeluarkan untuk memperoleh dan mencapai tujuan tertentu, sebaliknya beban adalah pengeluaran yang telah digunakan untuk menghasilkan prestasi (Satriani, Marheni, \& Miranda, 2015).

\section{Klasifikasi Biaya}

Klasifikasi biaya sangat penting untuk membuat ikhtisar yang berarti atas data biaya. Keberhasilan merencanakan serta mengendalikan biaya bergantung pada keseluruhan pemahaman atas hubungan antara biaya dan aktivitas bisnis. Dewi dan Kristanto (2014:11) mengklasifikasikan perilaku biaya sebagai berikut:

1) Biaya Tetap (Fixed Cost)

2) Biaya Variabel (Variable Cost)

3) Biaya Campuran (Mixed Cost)

Biaya tetap adalah biaya yang secara total tidak berubah saat aktivitas bisnis meningkat atau menurun sepanjang kapasitas normal. Biaya variabel didefinisikan sebagai biaya yang secara total meningkat secara proporsional terhadap peningkatan dalam aktivitas bisnis dan menurun secara proporsional terhadap penurunan dalam aktivitas bisnis. Sedangkan biaya campuran merupakan biaya yang memperlihatkan baik karakter-karakter dari biaya tetap maupun biaya variabel.

\section{Harga Pokok Produksi}

Harga pokok produksi (cost of goods manufactured) merupakan penjumlahan keseluruhan biaya yang dikeluarkan selama proses produksi hingga produk masuk dalam persediaan barang jadi selama periode tertentu (Raiborn dan Kinney, 2011:56). Biaya produksi (manufacturing cost) adalah biaya yang terjadi sehubungan dengan kegiatan manufaktur atau memproduksi suatu barang terdiri atas bahan 
langsung, tenaga kerja langsung dan overhead pabrik (Dunia dan Wasilah, 2012:42).

\section{Komponen Harga Pokok Produksi}

Dewi dan Kristanto (2014:21) menjelaskan Harga Pokok Produksi meliputi semua biaya yang dikeluarkan untuk membuat sebuah produk terjual. Harga Pokok Produksi digolongkan menjadi tiga komponen, yaitu:

1) Biaya bahan baku langsung.

2) Biaya tenaga kerja langsung.

3) Biaya overhead pabrik.

\section{Kegunaan Harga Pokok Produksi}

Bagi pelaku usaha sangat penting untuk mengetahui jumlah laba atau rugi yang dihasilkan pada satu periode tertentu yang didapat dari pengurangan pendapatan dengan biaya yang dikorbankan. Oleh karena itu diperlukan informasi harga pokok produksi.

Mulyadi (2012:65) manfaat penentuan harga pokok produksi adalah sebagai berikut:

1) Menentukan harga jual produk.

2) Memantau realisasi biaya produksi.

3) Menghitung laba atau rugi bruto periode tertentu.

4) Menentukan harga pokok persediaan produk jadi dan produk dalam proses yang disajikan dalam neraca.

\section{Metode Penentuan Harga Pokok Produksi}

Penentuan Harga Pokok Produksi ialah membebankan semua biaya produksi untuk menghasilkan sebuah produk, menentukan Harga Pokok Produksi berkenaan dengan biaya produk jadi dan jumlah persediaan barang dalam proses (Mangerongkonda et. al., 2014). Dalam menentukan Harga Pokok Produksi terdapat dua metode:

1) Full Costing,

2) Variable Costing.

\section{Harga Jual Produk}

Harga adalah jumlah uang yang dibutuhkan untuk mendapatkan sejumlah kombinasi dari barang beserta pelayanannya (Murti dan Soeprihanto, 2007:281). Menurut Tjiptono (2010:151) harga adalah suatu nilai untuk mendapatkan suatu produk kepada konsumen manfaat dari memiliki atau menggunakan pada satu waktu tertentu. Setiap perusahaan harus menetapkan harga jual produk secara tepat agar dapat sukses dalam memasarkan suatu barang atau jasa.

\section{Penentuan Harga Jual Produk}

Keputusan penentuan harga adalah keputusan manajemen tentang apa yang harus dibebankan kepada produk atau jasa (Hongren et al., 2008:494). Keputusan penentuan harga jual produk mempengaruhi kuantitas yang diproduksi dan dijual sehingga mempengaruhi pendapatan yang diterima perusahaan serta biaya yang dikeluarkan perusahaan.

\section{Tujuan Penetapan Harga Jual Produk}

Tujuan perusahaan dalam menetapkan harga jual ada bermacam-macam, semakin jelas tujuan suatu perusahaan maka akan semakin mudah menetapkan harga jual produk. Menurut Kotler (2007:84) tujuan penetapan harga jual yang dilakukan perusahaan adalah sebagai berikut:

1) Kelangsungan hidup perusahaan.

2) Memaksimalkan laba.

3) Kepemimpinan mutu produk.

4) Meningkatkan penjualan.

5) Mempertahankan dan memperluas pangsa pasar.

6) Menstabilkan harga.

\section{Proses Penetapan Harga Jual Produk}

Penetapan harga jual produk harus dilakukan dalam beberapa tahapan yang harus diperhitungkan oleh pelaku usaha. Menurut Boyd et al., (2000) tahapan penetapan harga jual produk adalah sebagai berikut:

1) Tujuan penetapan harga.

2) Memperkirakan permintaan untuk barang yang dijual dan elastisitas harganya.

3) Mengantisipasi reaksi dalam persaingan.

4) Menentukan pangsa pasar yang dapat diharapkan.

5) Memilih strategi harga untuk mencapai pasar sasaran. Pelaku usaha dapat memilih dua macam strategi harga yang dianggap esktrim, yaitu:
a. Skim-the-cream-pricing.
b. Penetration pricing.

6) Mempertimbangkan kebijakan pemasaran perusahaan.

7) Memilih metode penetapan harga. Terdapat tiga metode untuk menetapkan harga jual yaitu:

a. Penetapan harga yang berorientasi pada biaya; 

b. Penetapan harga yang berorientasi pada persaingan;
c. Penetapan harga yang berorientasi pada permintaan atau pelanggan

\section{UMKM}

UMKM adalah kelompok usaha yang dapat bertahan ketika krisis ekonomi melanda (Ardiana et al., 2010). UMKM memainkan peran penting dalam mengembangkan perekonomian negara karena membentuk sebagian besar kegiatan bisnis (Koe et al., 2015). UMKM dapat mencapai tingkat produktivitas suatu negara, meningkatkan pertumbuhan perekonomian dan memberikan kesempatan atau peluang kerja untuk mengurangi pengangguran (Jaime Diaz Saenz, 2010). UMKM ialah sebuah kegiatan dalam bidang perekonomian yang dilakukan oleh pelaku usaha termasuk pelaku usaha yang berada di Provinsi Aceh, khususnya kota Banda Aceh.

Secara ringkas berikit adalah kerangka pemikiran penelitian ini:

Skema Kerangka Pemikiran

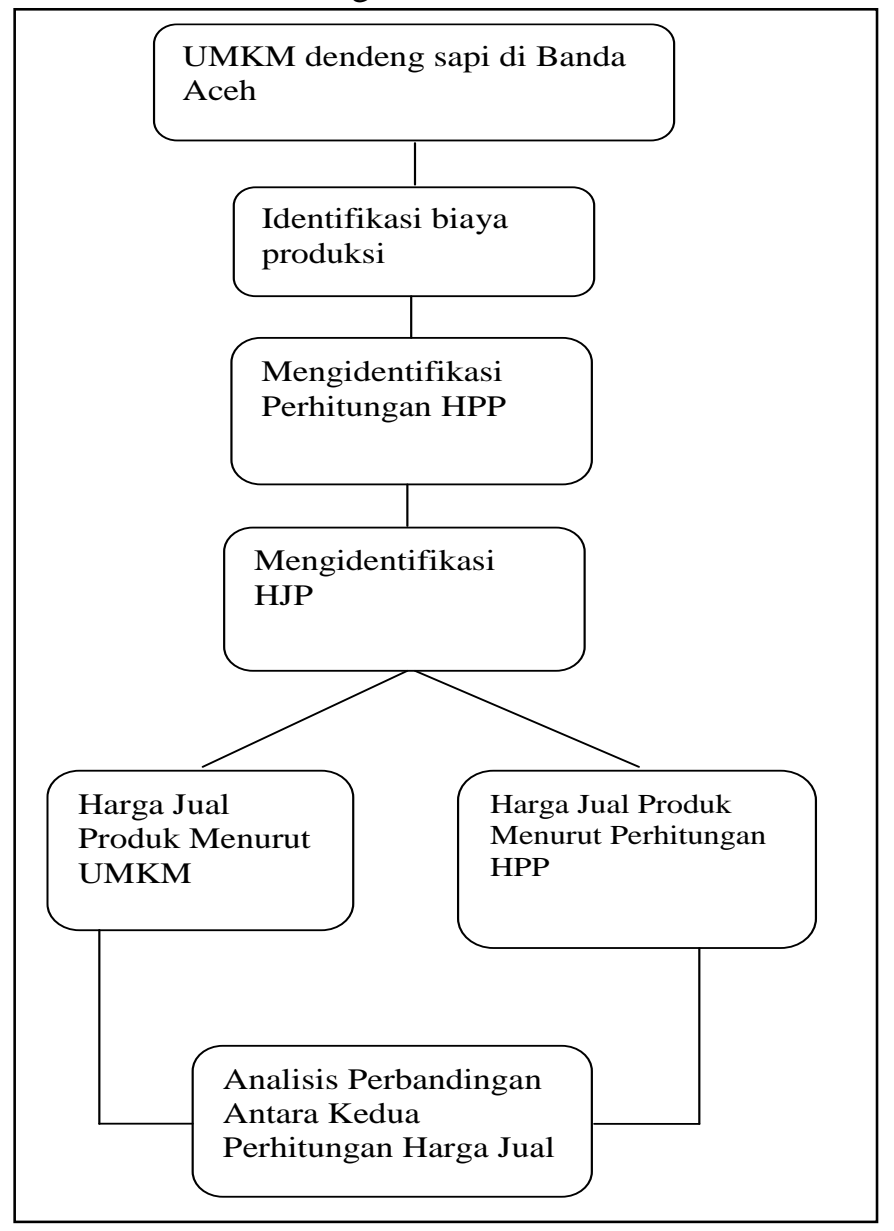

\section{Metode Penelitian Desain Penelitian}

Tujuan penlitian yang dilakukan pada studi ini adalah guna menganalisis penentuan harga pokok produksi dalam menetapkan harga jual produk dendeng sapi di UMKM dendeng sapi Banda Aceh. Jenis investigasi yang digunakan dalam penelitian ini adalah korelasional.Unit analisis penelitian ini adalah organisasi di bidang industri pengolahan makanan, dimana UMKM dendeng sapi yang menjadi unit analisis.

\section{Populasi dan Sampel Penelitian}

Populasi penelitian merupakan keseluruhan kelompok, orang, kejadian, atau sesuatu yang ingin diinvestigasi (Sekaran dan Bogie, 2016:236). Populasi untuk penelitian ini adalah seluruh UMKM dendeng sapi di Banda Aceh yang masih aktif berproduksi dan tertera nama UMKM tersebut di Badan Pusat Statistik pada tahun 2015. Teknik pengambilan sampel yang digunakan adalah purposive sampling.

\section{Sumber dan Teknik Pengumpulan Data}

Sumber data pada penelitian ini adalah data primer dan data sekunder.Data primer yang digunakan pada penelitian ini melaui wawancara kepada setiap pemilik usaha dendeng sapi yang akan diteliti. Data sekunder yang mendukung pada penelitian ini meliputi bahan kepustakaan sebagai data referensi penelitian seperti jumlah UMKM beserta data lengkap yang diambil dari BPS (Badan Pusat Statistika) dan bukubuku literatur yang bersangkutan dengan penelitian.

\section{Metode Analisis}

Teknik analisis data yang akan diterapkan adalah analisis deskriptif. Metode ini merupakan metode yang menguraikan dan menggambarkan suatu data atau keadaan yang melukiskan serta menjelaskan keadaan yang dituangkan menjadi sebuah kesimpulan dalam menjawab permasalahan yang akan dipecahkan (Murthosiyah et al., 2015). Adapun prosedur yang akan diterapkan dalam penelitian ini adalah sebagai berikut:

1. Mengidentifikasi biaya produksi

2. Mendeskripsikan perhitungan Harga Pokok Produksi perusahaan dengan menjabarkan biayabiaya produksi yang dikeluarkan oleh perusahaan dalam suatu periode tertentu. Perhitungan Harga 
Pokok Produksi dapat dilakukan dengan dua cara yaitu dengan metode full costing dan variabel costing. Berikut adalah gambaran perhitungan Harga Pokok Produksi berdasarkan kedua metode tersebut.

\begin{tabular}{|ll|lc|}
\hline Full Costing & Variable Costing \\
\hline Biaya bahan baku langsung & $\mathrm{xxx}$ & Biaya bahan baku langsung $\mathrm{xxx}$ \\
Biaya tenaga kerja langsung & $\mathrm{xxx}$ & Biaya tenaga kerja langsung $\mathrm{xxx}$ \\
Biaya overhead pabrik tetap & $\mathrm{xxx}$ & Biaya overhead pabrik variabel $\quad \underline{\mathrm{xxx}}$ \\
Biaya overhead pabrik variabel & $\underline{\mathrm{xxx}}$ & Harga pokok produksi & $\mathrm{xxx}$ \\
Harga pokok produksi & & & \\
& & & \\
& & & \\
\hline
\end{tabular}

3. Mendeskripsikan penghitungan harga jual. Penghitungan harga jual perusahaan manufaktur adalah sebagai berikut.

$$
\text { Harga Jual = Harga Pokok Produksi + }
$$

4. Didasarkan analisis penentuan harga pokok produksi yang dilakukan, maka diperoleh harga jual produk berdasarkan penentuan harga pokok produksi tersebut. Peneliti dapat melihat perbandingan harga jual produk yang ditetapkan perusahaan selama ini dengan harga jual produk yang diperoleh melalui analisis perhitungan harga pokok produksi.

4. Hasil Penelitian

Perhitungan Harga Pokok Produksi Dendeng Sapi di Banda Aceh

Tabel 4.1

Harga Pokok Produksi Menurut UMKM Dendeng Sapi di Banda Aceh Tahun 2017

\begin{tabular}{|c|c|c|c|c|c|c|}
\hline No & Uraian Biaya & \multicolumn{2}{|c|}{ Gunung Seulawah } & \multicolumn{2}{|c|}{ Bungong Jaroe } & Rencong Aceh \\
\hline 1 & Bahan Baku Langsung & $\mathrm{Rp}$ & 7.011 .640 .000 & $\mathrm{Rp}_{2}^{2}$ & .801 .018 .000 & Rp185.715.700 \\
\hline 2 & Tenaga Kerja Langsung & & 162.160 .000 & $\mathrm{Rp}$ & 109.200 .000 & Rp 32.400 .000 \\
\hline \multirow[t]{6}{*}{3} & Biaya Overhead Pabrik & & & & & \\
\hline & -Biaya Bahan Penolong & $\mathrm{Rp}$ & 216.160 .000 & & & \\
\hline & -Biaya Listrik & $\mathrm{Rp}$ & 10.293 .000 & $\mathrm{Rp}$ & 55.530 .000 & 5.107 .000 \\
\hline & -Biaya Air & $\mathrm{Rp}$ & 4.140 .000 & $\mathrm{Rp}$ & 2.474 .000 & 335.000 \\
\hline & PDAM & & & - & & - \\
\hline & -Biaya TKTL & - & & $\mathrm{Rp}$ & 30.000 .000 & - \\
\hline \multicolumn{2}{|c|}{ Total Biaya Produksi } & \multicolumn{2}{|r|}{$\operatorname{Rp} 7.404 .233 .000$} & \multicolumn{2}{|r|}{ Rp2.965.566.016 } & Rp223.557.700 \\
\hline \multicolumn{2}{|c|}{ Jumlah Produksi Per Kg } & \multicolumn{2}{|r|}{42.000} & \multicolumn{2}{|r|}{18.000} & 1.200 \\
\hline \multicolumn{2}{|c|}{ Harga Pokok Produksi Per Kg } & & 176.292 & & 164.754 & 186.300 \\
\hline
\end{tabular}

Sumber: Diolah dari data primer UMKM Dendeng Sapi di Banda Aceh, 2018

Tabel 4.2

Rata-Rata Harga Pokok Produksi MenurutUMKM Dendeng Sapi di Banda Aceh Tahun 2017

\begin{tabular}{llc}
\hline No & Nama UMKM & Harga Pokok Produksi Per Kg \\
\hline 1 & Gunung Seulawah & Rp 176.292 \\
\hline 2 & Bungong Jaroe & Rp 166.568 \\
\hline 3 & Rencong Aceh & Rp 186.300 \\
\hline
\end{tabular}




\begin{tabular}{ll}
\hline Total & Rp 529.160 \\
\hline Rata-Rata & Rp 176.386 \\
\hline
\end{tabular}

Sumber: Diolah dari data primer UMKM Dendeng Sapi di Banda Aceh, 2018

Tabel 4.3

Harga Pokok Produksi Dendeng Sapi Menggunakan Metode Full Costing Tahun 2017

\begin{tabular}{|c|c|c|c|c|c|c|c|}
\hline No & Uraian Biaya & Gui & ung Seulawah & Bur & gong Jaroe & Ren & ong Aceh \\
\hline 1 & Bahan Baku Langsung & $\mathrm{Rp}$ & .011 .640 .000 & $\mathrm{Rp} 2$ & 801.018 .000 & Rp1 & 35.715 .700 \\
\hline 2 & Tenaga Kerja Langsung & $\mathrm{Rp}$ & 129.600 .000 & $\mathrm{Rp}$ & 84.000 .000 & $\mathrm{Rp}$ & 21.600 .000 \\
\hline 3 & Biaya Overhead Pabrik & & & & & & \\
\hline & -Biaya Bahan Penolong & & & & & & \\
\hline & -Biaya Listrik & $\mathrm{Rp}$ & 216.160 .000 & $\mathrm{Rp}$ & 55.530 .000 & $\mathrm{Rp}$ & 5.107 .000 \\
\hline & -Biaya Air PDAM & & & & & & \\
\hline & -Biaya TKTL & $\mathrm{Rp}$ & 10.293 .000 & $\mathrm{Rp}$ & 2.474 .000 & $\mathrm{Rp}$ & 335.000 \\
\hline & -Biaya Angkut & $\mathrm{Rp}$ & 4.140 .000 & - & & - & \\
\hline & -Biaya Perawatan Mesin & - & & $\mathrm{Rp}$ & 18.000 .000 & - & \\
\hline & -Biaya Penyusutan Mesin & $\mathrm{Rp}$ & 2.464 .000 & $\mathrm{Rp}$ & 1.743 .000 & $\mathrm{Rp}$ & 810.000 \\
\hline & & $\mathrm{Rp}$ & 900.000 & $\mathrm{Rp}$ & 350.000 & $\mathrm{Rp}$ & 127.500 \\
\hline & & $\mathrm{Rp}$ & 3.386 .386 & $\mathrm{Rp}$ & 2.451 .016 & $\mathrm{Rp}$ & 768.900 \\
\hline Tot & Biaya Produksi & & Rp 7.378.583.386 & & Rp2.965.566.016 & & Rp214.464.100 \\
\hline Jum & ah Produksi Per Kg & & 42.000 & & 18.000 & & .200 \\
\hline Har & a Pokok Produksi Per Kg & & 175.680 & & 164.754 & & 178.720 \\
\hline
\end{tabular}

Sumber: Diolah dari data primer UMKM Dendeng Sapi di Banda Aceh, 2018

Tabel 4.4

Rata-Rata Harga Pokok Produksi Dendeng Sapi Menggunakan Metode Full Costing Tahun 2017

\begin{tabular}{lll}
\hline Menurut UMKM & Metode Full Costing & Selisih \\
\hline Rp 176.386 & Rp 173.051 & Rp 3.335 \\
\hline
\end{tabular}

Sumber: Diolah dari data primer UMKM Dendeng Sapi di Banda Aceh, 2018

Tabel 4.5

Selisih Rata-Rata Harga Pokok Produksi Menurut UMKM dengan Metode Full Costing

\begin{tabular}{lll}
\hline No & Nama UMKM & Harga Pokok Produksi Per Kg \\
\hline 1 & Gunung Seulawah & Rp 175.680 \\
\hline 2 & Bungong Jaroe & Rp 164.754 \\
\hline 3 & Rencong Aceh & Rp 178.720 \\
\hline Total & & Rp 519.154 \\
\hline Rata-Rata & & Rp 173.051
\end{tabular}

Sumber: Diolah dari data primer UMKM Dendeng Sapi di Banda Aceh, 2018

Rata-rata harga pokok produksi dendeng sapi menurut perhitungan UMKM dendeng sapi di Banda Aceh sebesar Rp176.386 per kilogram dendeng sapi, sedangkan jika menghitung harga pokok produksi menggunakan metode full costing menunjukkan harga sebesar Rp173.051 per kilogram dendeng sapi. Selisih antara kedua perhitungan tersebut adalah Rp3.335 per kilogram dendeng sapi. 
Tabel 4.6

Harga Pokok Produksi Dendeng Sapi Menggunakan Metode Variable Costing Tahun 2017

\begin{tabular}{lllll}
\hline No & Uraian Biaya & Gunung Seulawah & Bungong Jaroe & Rencong Aceh \\
\hline 1 & Bahan Baku Langsung & 7.011 .640 .000 & 2.801 .018 .000 & 185.715 .700 \\
\hline 2 & Tenaga Kerja Langsung & 162.000 .000 & 109.200 .000 & 32.400 .000 \\
\hline 3 & $\begin{array}{l}\text { Biaya Overhead Pabrik } \\
\text {-Biaya Bahan Penolong }\end{array}$ & 216.160 .000 & 55.530 .000 & 5.107 .000 \\
& -Biaya Listrik & 10.293 .000 & 2.474 .000 & 335.000 \\
& -Biaya Air PDAM & 4.140 .000 & - & - \\
& -Biaya Angkut & 4.410 .000 & 2.905 .000 & 1.350 .000 \\
\hline Total Biaya Produksi & 7.408 .643 .000 & 2.971 .127 .000 & 224.907 .700 \\
\hline Jumlah Produksi Per Kg & 42.000 & 18.000 & 1.200 \\
\hline & Harga Pokok Produksi Per Kg & $\mathbf{1 7 6 . 3 9 6}$ & $\mathbf{1 6 5 . 0 6 3}$ & $\mathbf{1 8 7 . 4 2 3}$
\end{tabular}

Sumber: Diolah dari data primer UMKM Dendeng Sapi di Banda Aceh, 2018

Tabel 4.7

Rata-Rata Harga Pokok Produksi Dendeng Sapi Menggunakan Metode Variable Costing Tahun 2017

\begin{tabular}{llc}
\hline No & Nama UMKM & Harga Pokok Produksi Per Kg \\
\hline 1 & Gunung Seulawah & Rp 175.659 \\
\hline 2 & Bungong Jaroe & $\operatorname{Rp~164.734~}$ \\
\hline 3 & Rencong Aceh & $\operatorname{Rp~178.614~}$ \\
\hline Total & & $\operatorname{Rp~519.007}$ \\
\hline Rata-Rata & Rp 173.002 \\
\hline
\end{tabular}

Sumber: Diolah dari data primer UMKM Dendeng Sapi di Banda Aceh, 2018

Tabel 4.8

Selisih Rata-Rata Harga Pokok Produksi Menurut UMKM dengan Metode Variable Costing

\begin{tabular}{lll}
\hline Menurut UMKM & Metode Variable Costing & Selisih \\
\hline Rp 176.386 & Rp 173.002 & Rp 3.384 \\
\hline
\end{tabular}

Sumber: Diolah dari data primer UMKM Dendeng Sapi di Banda Aceh, 2018

Rata-rata perolehan harga pokok produksi yang selama ini digunakan UMKM dendeng sapi di Banda Aceh adalah Rp176.386 per kilogram, sedangkan jika UMKM menggunakan metode variable costing dalam menentukan harga pokok produksi sebesar Rp173.002 per kilogram dendeng sapi. Selisih antara kedua hitungan tersebut adalah Rp3.384 per kilogram. Selisisih jika menggunakan metode full costing adalah
Rp3.335 per kilogram. Hasil ini menunjukkan bahwa selisih menggunakan metode variable costing lebih tinggi dari pada menggunakan metode full costing.

Perbandingan Perhitungan Harga Pokok Produksi Menurut UMKM Dendeng Sapi di Banda Aceh dan Menurut Penerapan Metode Full Costing serta Variable Costing 
Tabel 4.9

Perhitungan Harga Pokok Produksi UMKM Gunung Seulawah Per Tahun

\begin{tabular}{|c|c|c|c|c|}
\hline No & Uraian Biaya Per Tahun & $\begin{array}{ll}\text { Perhitungan } & \text { UMKM }\end{array}$ & Full Costing & Variable Costing \\
\hline & & Gunung Seulawah & & \\
\hline 1 & Bahan Baku Langsung & Rp7.011.640.000 & Rp7.011.640.000 & Rp7.011.640.000 \\
\hline 2 & Tenaga Kerja Langsung & $\begin{array}{ll}\mathrm{Rp} & 162.000 .000\end{array}$ & Rp129.600.000 & Rp129.600.000 \\
\hline 3 & Biaya Overhead Pabrik & & & \\
\hline & -Biaya Bahan Penolong & Rp 216.160.000 & Rp 216.160.000 & Rp 216.160.000 \\
\hline & - Biaya Listrik & $\mathrm{Rp} \quad 10.293 .000$ & $\mathrm{Rp} \quad 10.293 .000$ & $\mathrm{Rp} \quad 10.293 .000$ \\
\hline & -Biaya Air PDAM & $\mathrm{Rp} \quad 4.140 .000$ & $\mathrm{Rp} \quad 4.140 .000$ & $\mathrm{Rp} \quad 4.140 .000$ \\
\hline & -Biaya TKTL & - & - & - \\
\hline & -Biaya Angkut & - & $\mathrm{Rp} \quad 2.464 .000$ & 2.464 .000 \\
\hline & -Biaya Perawatan & - & $\mathrm{Rp} \quad 900.000$ & - \\
\hline & Mesin & & & \\
\hline & -Biaya Penyusutan Mesin & - & $\mathrm{Rp} \quad 3.386 .386$ & 3.386 .386 \\
\hline & iaya Produksi & Rp7.404.233.000 & Rp7.378.583.386 & Rp7.377.683.386 \\
\hline & Produksi Per Kg & 42.000 & 42.000 & 42.000 \\
\hline & okok Produksi PerKg & 176.292 & 175.680 & 175.659 \\
\hline
\end{tabular}

Sumber: Diolah dari data primer UMKM Dendeng Sapi di Banda Aceh, 2018

Tabel 4.10

Selisih Harga Pokok Produksi Menurut UMKM Gunung Seulawah

\begin{tabular}{llllll}
\hline Metode Menurut UMKM & \multicolumn{2}{l}{ Metode Harga Pokok Produksi } & Selisih & Jumlah Produksi & Jumlah Selisih \\
\hline Rp 176.292 & Full Costing & Rp 175.680 & Rp 612 & 42.000 & Rp25.704.000 \\
\hline Rp 176.292 & Variable Costing & Rp 175.659 & Rp 633 & 42.000 & Rp26.586.000 \\
\hline
\end{tabular}

Sumber: Diolah dari data primer UMKM Dendeng Sapi di Banda Aceh, 2018

Harga pokok produksi yang selama ini ditentukan oleh UMKM Gunung Seulawah adalah Rp176.292per kilogram. Perhitungan harga pokok produksi UMKM Gunung Seulawah jika menggunakan metode full costing adalah Rp175.680 per kilogram. Selisih kedua perhitungan tersebut adalah Rp612 per kilogram dendeng sapi dengan jumlah produksi 42.000 kilogram pertahun, maka

Tabel 4.11

Perhitungan Harga Pokok Produksi UMKM Bungong Jaroe Per Tahun

\begin{tabular}{lllllr}
\hline \multicolumn{2}{c}{ No } & Uraian Biaya Per Tahun & \multicolumn{2}{c}{$\begin{array}{c}\text { Perhitungan UMKM } \\
\text { Bungong Jaroe }\end{array}$} & \multicolumn{2}{c}{ Full Costing } & Variable Costing \\
\hline 1 & Bahan Baku Langsung & $\mathrm{Rp} 2.801 .018 .000$ & $\mathrm{Rp} 2.801 .018 .000$ & $\mathrm{Rp} 2.801 .018 .000$ \\
\hline 2 & Tenaga Kerja Langsung & $\mathrm{Rp} 109.200 .000$ & $\mathrm{Rp} 84.000 .000$ & $\mathrm{Rp}$ & 84.000 .000 \\
\hline
\end{tabular}

selisih selama satu tahun adalah Rp25.704.000. Harga pokok produksi UMKM Gunung Seulawah dengan menggunakan metode variable costing adalah sebesar Rp175.659 per kilogram. Selisih perhitungan kedua metode tersebut adalah Rp633 jika dikalikan jumlah produksi setahun adalah Rp26.596.000. 


\begin{tabular}{|c|c|c|c|c|c|}
\hline \multirow[t]{8}{*}{3} & \multicolumn{5}{|l|}{ Biaya Overhead Pabrik } \\
\hline & -Biaya Bahan Penolong & $\mathrm{Rp}$ & 55.530 .000 & Rp 55.530.000 & Rp 55.530.000 \\
\hline & - Biaya Listrik & $\mathrm{Rp}$ & 2.474 .000 & Rp 2.474 .000 & $\mathrm{Rp} \quad 2.474 .000$ \\
\hline & -Biaya Air PDAM & - & & - & - \\
\hline & -Biaya TKTL & $\mathrm{Rp}$ & 30.000 .000 & Rp 18.000 .000 & Rp 18.000.000 \\
\hline & -Biaya Angkut & - & & $\operatorname{Rp} 1.743 .000$ & $\mathrm{Rp} \quad 1.743 .000$ \\
\hline & -Biaya Perawatan Mesin & - & & $\mathrm{Rp} \quad 350.000$ & - \\
\hline & -Biaya Penyusutan Mesin & - & & Rp 2.451 .016 & $\mathrm{Rp} \quad 2.451 .016$ \\
\hline \multicolumn{2}{|c|}{ Total Biaya Produksi } & \multicolumn{2}{|c|}{ Rp2.998.222.000 } & Rp2.965.566.016 & Rp2.965.216.016 \\
\hline \multicolumn{2}{|c|}{ Jumlah Produksi Per Kg } & \multicolumn{2}{|c|}{18.000} & 18.000 & 18.000 \\
\hline & kok Produksi Per Kg & $\mathbf{R p}$ & 166.568 & 164.754 & 164.734 \\
\hline
\end{tabular}

Sumber: Diolah dari data primer UMKM Dendeng Sapi di Banda Aceh, 2018

Tabel 4.12

Selisih Harga Pokok Produksi Menurut UMKM Bungong Jaroe

\begin{tabular}{llllll}
\hline $\begin{array}{c}\text { Metode Menurut } \\
\text { UMKM }\end{array}$ & \multicolumn{2}{c}{ Metode Harga Pokok Produksi } & Selisih & Jumlah Produksi & Jumlah Selisih \\
\hline Rp 166.568 & Full Costing & Rp 164.754 & Rp 1.814 & 18.000 & Rp32.652.000 \\
\hline Rp 166.568 & Variable Costing & Rp 164.734 & Rp 1.834 & 18.000 & Rp33.012.000 \\
\hline
\end{tabular}

Sumber: Diolah dari data primer UMKM Dendeng Sapi di Banda Aceh, 2018

Pada UMKM Bungong Jaroe perhitungan harga pokok produksi yang selaam ini diterapkan adalah Rp166.586per kilogram, sedangkan perhitungan harga pokok produksi menggunakan metode full costing sebesar Rp164.754 per kilogram. Selisisih dari kedua hitungan ini adalah Rp1.814 per kilogram dendeng sapi dengan jumlah produksi dendeng sapi sebesar 18.000 kilogram pertahun, maka selisih selama satu tahun adalah Rp32.652.000.
Perhitungan harga pokok produksi menggunakan metode variable costing adalah Rp164.734 per kilogram. Selisih perhitungan metode ini dengan metode yang diterapkan UMKM Bungong Jaroe selama ini adalah Rp1.834 per kilogram dendeng sapi, sehingga selisih selama satu tahun dengan jumlah produkis sebesar 18.000 kilogram adalah Rp33.012.000.

Tabel 4.13

Perhitungan Harga Pokok Produksi UMKM Rencong Aceh Per Tahun

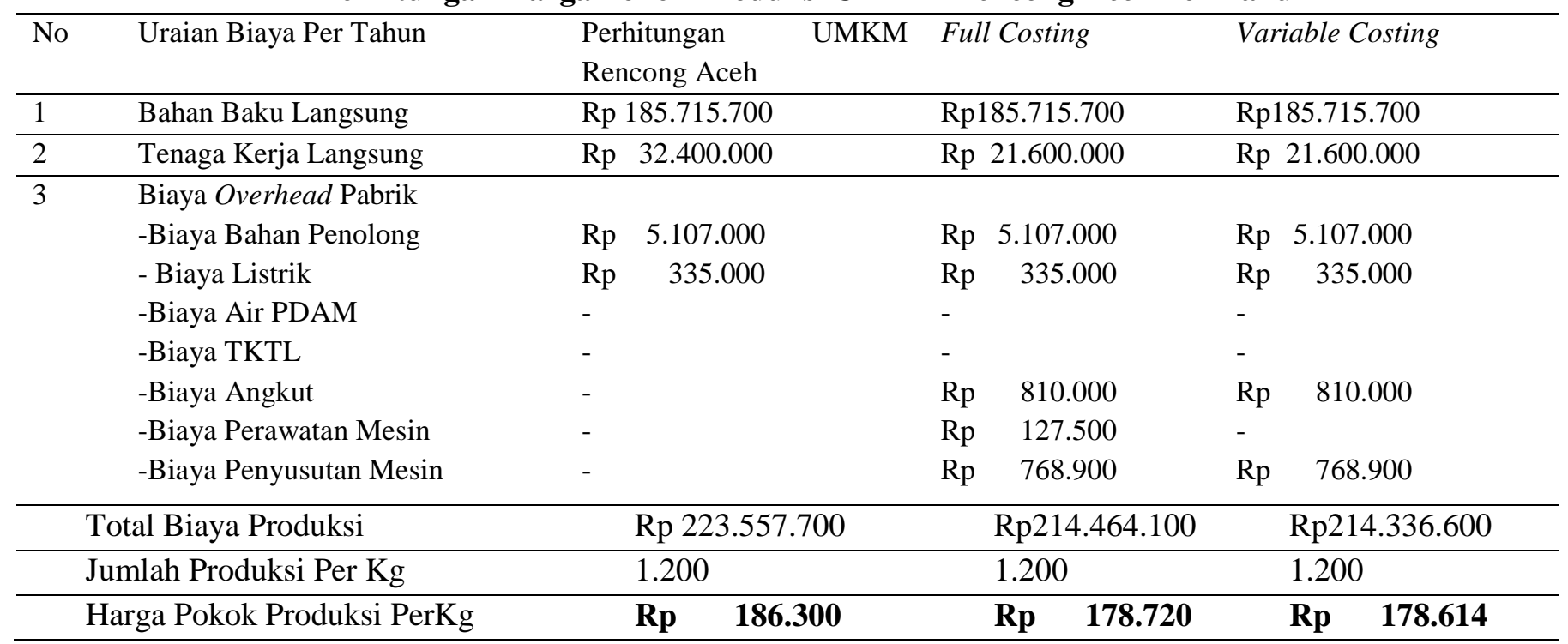

Sumber: Diolah dari data primer UMKM Dendeng Sapi di Banda Aceh, 2018 
Tabel 4.14

Selisih Harga Pokok Produksi Menurut UMKM Rencong Aceh

\begin{tabular}{|c|c|c|c|c|c|}
\hline Metode Menurut UMKM & Metode $\mathbf{H}$ & arga Pokok Produksi & Selisih & $\begin{array}{l}\text { Jumlah } \\
\text { Produksi }\end{array}$ & Jumlah Selisih \\
\hline Rp 186.300 & $\begin{array}{l}\text { Full } \\
\text { Costing }\end{array}$ & Rp 178.720 & Rp 7.580 & 1.200 & Rp9.096.000 \\
\hline Rp 186.300 & $\begin{array}{l}\text { Variable } \\
\text { Costing }\end{array}$ & Rp 178.614 & Rp 7.686 & 1.200 & Rp9.223.200 \\
\hline
\end{tabular}

Sumber: Diolah dari data primer UMKM Dendeng Sapi di Banda Aceh, 2018

Harga Pokok Produksi UMKM Rencong Aceh selama ini adalah Rp186.300 per kilogram sedangkan harga pokok produksi UMKM Rencong Aceh menggunakan metode full costing adalah Rp178.720 per kilogram. Selisih antara kedua perhitungan tersebut adalah Rp7.580 per kilogram dengan jumlah produksi dendeng sapi sebanyak 1.200 kilogram setahun maka selisih kedua perhitungan tersebut adalah Rp9.096.000 pertahun. Perhitungan harga pokok produksi UMKM Rencong Aceh menggunakan metode variable costing adalah Rp178.614 per

kilogram. Selisih perhitungan ini dengan perhitungan yang selama ini diterapkan UMKM Rencong Aceh adalah Rp7.686 per kilogram dendeng sapi dengan jumlah produksi dendeng sapi selama satu tahun adalah 1.200 kilogram maka selisih kedua metode ini adalah Rp9.223.200 per tahun.

Perbandingan Laba Menurut UMKM Dendeng Sapi di Banda Aceh dan Laba Metode Full Costing Serta Variable Costing

Tabel 4.15

Perbandingan Laba UMKM Gunung Seulawah

\begin{tabular}{|c|c|c|c|}
\hline & Menurut UMKM & Metode Full Costing & Metode Variable Costing \\
\hline Penjualan (42.000 kg x Rp 240.000) & Rp10.080.000.000 & Rp10.080.000.000 & Rp10.080.000.000 \\
\hline Harga Pokok Produksi & Rp 7.404.233.000 & Rp 7.378.583.386 & Rp 7.377.683.386 \\
\hline Laba Kotor & Rp 2.675.736.000 & Rp 2.701.416.614 & Rp 2.702.316.614 \\
\hline Beban Angkut & - & $\begin{array}{ll}\mathrm{Rp} & 1.764 .000\end{array}$ & $\begin{array}{ll}\mathrm{Rp} & 1.764 .000\end{array}$ \\
\hline Laba Bersih & Rp 2.675.736.000 & Rp 2.699.652.614 & Rp 2.700.552.614 \\
\hline
\end{tabular}

Sumber: Diolah dari data primer UMKM Dendeng Sapi di Banda Aceh, 2018

Tabel 4.16

Selisih Laba UMKM Gunung Seulawah

\begin{tabular}{lllc}
\hline Laba Menurut UMKM & \multicolumn{2}{c}{ Metode Harga Pokok Produksi } & Jumlah Selisih \\
\hline $\mathrm{Rp} 2.675 .736 .000$ & Full Costing & $\mathrm{Rp} 2.699 .652 .614$ & Rp 23.916.614 \\
\hline $\mathrm{Rp} 2.675 .736 .000$ & Variable Costing & $\mathrm{Rp} 2.700 .552 .614$ & Rp 24.816.614 \\
\hline
\end{tabular}

Sumber: Diolah dari data primer UMKM Dendeng Sapi di Banda Aceh, 2018

Tabel 4.17

Perbandingan Laba UMKM Bungong Jaroe

\begin{tabular}{|c|c|c|c|}
\hline & Menurut UMKM & Metode Full Costing & Metode Variable Costing \\
\hline Penjualan (18.000 kg x Rp 220.000) & Rp 3.960.000.000 & $\operatorname{Rp} 3.960 .000 .000$ & Rp 3.960.000.000 \\
\hline Harga Pokok Produksi & $\operatorname{Rp} 2.998 .222 .000$ & $\operatorname{Rp} 2.965 .566 .016$ & $\operatorname{Rp} 2.965 .216 .016$ \\
\hline Laba Kotor & $\begin{array}{ll}\mathrm{Rp} & 961.778 .000\end{array}$ & Rp 994.433 .984 & $\begin{array}{ll}\mathrm{Rp} & 994.783 .984\end{array}$ \\
\hline Beban Angkut & - & 1.162 .000 & 1.162 .000 \\
\hline Laba Bersih & Rp $\quad 961.778 .000$ & 993.271.984 & Rp 993.621.984 \\
\hline
\end{tabular}

Sumber: Diolah dari data primer UMKM Dendeng Sapi di Banda Aceh, 2018 
Tabel 4.18

Selisih Laba UMKM Bungong Jaroe

\begin{tabular}{llll}
\hline Laba Menurut UMKM & \multicolumn{2}{l}{ Metode Harga Pokok Produksi } & Jumlah Selisih \\
\hline Rp 961.778.000 & Full Costing & Rp 993.271.984 & Rp 31.493.984 \\
\hline Rp 961.778.000 & Variable Costing & Rp 993.621.984 & Rp 31.843.984 \\
\hline
\end{tabular}

Sumber: Diolah dari data primer UMKM Dendeng Sapi di Banda Aceh, 2018

Tabel 4.19

Perbandingan Laba UMKM Rencong Aceh

\begin{tabular}{|c|c|c|c|}
\hline & Menurut UMKM & Metode Full Costing & Metode Variable Costing \\
\hline Penjualan (1.200 kg x Rp 240.000) & Rp 288.000.000 & $\mathrm{Rp} 288.000 .000$ & $\mathrm{Rp} 288.000 .000$ \\
\hline Harga Pokok Produksi & Rp 233.557.700 & Rp 214.464.100 & P 214.336.600 \\
\hline Laba Kotor & Rp 54.442 .300 & Rp 73.535 .900 & $\operatorname{Rp} 73.664 .000$ \\
\hline Beban Angkut & Rp $\quad 540.000$ & $\mathrm{Rp} \quad 540.000$ & $\mathrm{Rp} \quad 540.000$ \\
\hline Laba Bersih & Rp 53.902.300 & Rp 72.995 .900 & Rp 72.995.900 \\
\hline
\end{tabular}

Sumber: Diolah dari data primer UMKM Dendeng Sapi di Banda Aceh, 2018

Tabel 4.20

Selisih Laba UMKM Rencong Aceh

\begin{tabular}{llll}
\hline Laba Menurut UMKM & \multicolumn{2}{l}{ Metode Harga Pokok Produksi } & Jumlah Selisih \\
\hline Rp 53.902.300 & Full Costing & Rp 72.995.900 & Rp 19.093.600 \\
\hline Rp 53.902.300 & Variable Costing & Rp 72.995.900 & Rp 19.093.600 \\
\hline
\end{tabular}

Sumber: Diolah dari data primer UMKM Dendeng Sapi di Banda Aceh, 2018

Perbandingan Penentuan Harga Jual Produk Menurut UMKM Dendeng Sapi Sapi di Banda Aceh dan Penentuan Harga Jual Produk Menurut Metode Cost Plus Pricing

Tabel 4.21

Perhitungan Harga Jual Produk Menurut Harga Pokok Poduksi Full Costing Pendekatan Metode Cost Plus Pricing

\begin{tabular}{|c|c|c|c|}
\hline Uraian & UMKM Gunung Seulawah & UMKM Bungong Jaroe & UMKM Rencong Aceh \\
\hline -Produk Terjual & 42.000 & 18.000 & 1.200 \\
\hline \multicolumn{4}{|l|}{-Biaya Penuh } \\
\hline - Metode Full Costing & Rp 7.378.583.386 & Rp2.965.566.016 & Rp214.464.100 \\
\hline - Beban lainnya & $\mathrm{Rp} \quad 1.764 .000$ & $\mathrm{Rp} \quad 1.162 .000$ & $\mathrm{Rp} \quad 540.000$ \\
\hline -Total Biaya Penuh & Rp 7.380.347.386 & Rp2.966.728.016 & Rp215.004.100 \\
\hline -Total Biaya Per Kg & $\mathrm{Rp} \quad 175.723$ & $\mathrm{Rp} \quad 164.818$ & $\mathrm{Rp} \quad 179.170$ \\
\hline -Laba UMKM & Rp 2.675.736.000 & Rp 961.778.000 & Rp 53.902.300 \\
\hline -Laba Bersih Per Kg & 63.708 & 53.432 & 49.920 \\
\hline -Total Penjualan & Rp10.056.083.386 & Rp3.928.506.016 & Rp268.906.400 \\
\hline -Harga Jual Per Kg & Rp $\quad 239.430$ & Rp $\quad 218.250$ & Rp $\quad 224.089$ \\
\hline
\end{tabular}

Sumber: Diolah dari data primer UMKM Dendeng Sapi di Banda Aceh, 2018 
Tabel 4.22

Perbandingan Harga Jual Produk Menurut UMKM dengan Harga Jual Produk Menurut Harga Pokok Produksi Full Costing Pendekatan Metode Cost Plus Pricing

\begin{tabular}{|c|c|c|c|c|c|}
\hline $\begin{array}{l}\text { Nama } \\
\text { UMKM }\end{array}$ & $\begin{array}{l}\text { Harga Jual } \\
\text { Produk } \\
\text { Menurut } \\
\text { UMKM }\end{array}$ & $\begin{array}{c}\text { Harga Jual Produk } \\
\text { Menurut HPP Variable } \\
\text { Costing Pendekatan } \\
\text { Metode Cost Plus Pricing }\end{array}$ & $\begin{array}{c}\text { Selisih Harga Jual UMKM } \\
\text { dengan Metode Cost Plus } \\
\text { Pricing HPP Variable } \\
\text { Costing }\end{array}$ & $\begin{array}{l}\text { Jumlah Produksi } \\
\text { Per Tahun }\end{array}$ & $\begin{array}{l}\text { Jumlah Selisih } \\
\text { Perbandingan }\end{array}$ \\
\hline $\begin{array}{l}\text { Gunung } \\
\text { Seulawah }\end{array}$ & Rp 240.000 & $\operatorname{Rp} 239.409$ & Rp 591 & 42.000 & Rp24.822.000 \\
\hline $\begin{array}{l}\text { Bungong } \\
\text { Jaroe }\end{array}$ & Rp 220.000 & Rp 218.231 & Rp 1.769 & 18.000 & Rp31.842.000 \\
\hline $\begin{array}{l}\text { Rencong } \\
\text { Aceh }\end{array}$ & Rp 240.000 & Rp 223.981 & Rp 16.019 & 1.200 & Rp19.222.800 \\
\hline
\end{tabular}

Sumber: Diolah dari data primer UMKM Dendeng Sapi di Banda Aceh, 2018

UMKM Gunung Seulawah menerapkan perhitungan harga pokok produksi metode full costing dan menetapkan harga jual produk menggunakan metode cost plus pricing maka harga jual produk yang selama ini diterapkan oleh UMKM Gunung Seulawah adalah terlalu tinggi. UMKM Bungong Jaroe selama ini menetapkan harga jual produk terlalu tinggi jika UMKM Bungong Jaroe menerapkan harga pokok produksi menggunakan metode full costing dan menetapkan harga jual produk dengan metode cost plus pricing. UMKM Rencong Aceh selama ini menetapkan harga jual produk juga lebih tinggi jika UMKM Rencong Aceh menghitung harga pokok produksi dengan menggunakan metode full costing dan menetapkan harga jual dengan menggunakan metode cost plus pricing.

Tabel 4.23

Perhitungan Harga Jual Menurut Harga Pokok Poduksi Variable Costing Pendekatan Metode Cost Plus

\section{Pricing}

\begin{tabular}{|c|c|c|c|}
\hline Uraian & UMKM Gunung Seulawah & UMKM Bungong Jaroe & UMKM Rencong Aceh \\
\hline -Produk Terjual & 42.000 & 18.000 & 1.200 \\
\hline \multicolumn{4}{|l|}{-Biaya Penuh } \\
\hline $\begin{array}{l}\text { - Harga Pokok Produksi } \\
\text { (Variable Costing) }\end{array}$ & Rp 7.377.683.386 & Rp2.965.216.016 & Rp214.336.000 \\
\hline - Beban lainnya & 1.764 .000 & 1.162 .000 & 540.000 \\
\hline -Total Biaya & Rp 7.379.447.386 & $\operatorname{Rp} 2.966 .378 .016$ & Rp214.876.000 \\
\hline -Total Biaya Per Kg & $\mathrm{Rp} \quad 175.701$ & Rp $\quad 164.800$ & Rp $\quad 179.063$ \\
\hline -Total Laba Bersih & Rp 2.675.736.000 & Rp $\quad 961.778 .000$ & Rp 53.902.300 \\
\hline - Laba Bersih Per Kg & $\begin{array}{ll}\mathrm{Rp} & 63.708\end{array}$ & $\mathrm{Rp} \quad 53.432$ & $\mathrm{Rp} \quad 44.919$ \\
\hline - Total Penjualan & Rp10.055.183.386 & Rp 3.928.156.016 & Rp268.778.300 \\
\hline -Harga Jual Per Kg & Rp $\quad 239.409$ & Rp $\quad 218.231$ & Rp $\quad 223.981$ \\
\hline
\end{tabular}

Sumber: Diolah dari data primer UMKM Dendeng Sapi di Banda Aceh, 2018 
Tabel 4.24

Perbandingan Harga Jual Produk Menurut UMKM dengan Harga Jual Produk Menurut Harga Pokok Produksi Variable Costing Pendekatan Metode Cost Plus Pricing

\begin{tabular}{cccccc}
\hline Nama UMKM & $\begin{array}{c}\text { Harga Jual } \\
\text { Produk Menurut } \\
\text { UMKM }\end{array}$ & $\begin{array}{c}\text { Harga Jual Produk Menurut } \\
\text { HPP Full Costing } \\
\text { Pendekatan Metode Cost } \\
\text { Plus Pricing }\end{array}$ & $\begin{array}{c}\text { Selisih Harga Jual } \\
\text { UMKM dengan Metode } \\
\text { Cost Plus Pricing HPP } \\
\text { Full Costing }\end{array}$ & $\begin{array}{c}\text { Jumlah } \\
\text { Produksi } \\
\text { Per Tahun }\end{array}$ & $\begin{array}{c}\text { Jumlah Selisih } \\
\text { Perbandingan }\end{array}$ \\
\hline $\begin{array}{c}\text { Gunung } \\
\text { Seulawah }\end{array}$ & 240.000 & 249.765 & 9.765 & 42.000 & 410.130 .000 \\
\hline Bungong Jaroe & 220.000 & 229.180 & 9.180 & 18.000 & 165.240 .000 \\
\hline Rencong Aceh & 240.000 & 247.472 & 7.472 & 1.200 & 8.966 .400 \\
\hline
\end{tabular}

Sumber: Diolah dari data primer UMKM Dendeng Sapi di Banda Aceh, 2018

UMKM Gunung Seulawah selama ini lebih tinggi jika UMKM terebut menggunakan harga pokok produksi metode variable costing dan menetapkan harga jual produk dengan metode cost plus pricing. Pada UMKM Bungong Jaroe juga menetapkan harga jual lebih tinggi jika UMKM tersebut menghitung harga pokok produksi dengan metode variable costing dan menetapkan harga jual produk dengan menggunakan metode cost plus pricing. UMKM Rencong Aceh juga selama ini juga menetapkan harga jual lebih tinggi dibanding jika UMKM tersebut menggunakan perhitungan harga pokok produksi dengan metode variable costing dan menetapkan harga jual produk dengan menggunakan metode cost plus pricing.

\section{Kesimpulan \\ Kesimpulan}

Berdasarkan hasil penelitian yang diperoleh, maka dapat disimpulkan sebagai berikut:

1) UMKM dendeng sapi di Banda Aceh selama ini tidak menghitung harga pokok produksi.

2) UMKM dendeng sapi di Banda Aceh menetapkan harga jual produknya hanya mengikuti harga pasar tanpa melakukan perhitungan harga pokok produksi

3) Hasil menunjukkan bahwa perolehan harga pokok produksi menggunakan metode full costing maupun variable costing lebih tepat digunakan UMKM untuk memperoleh peningkatan laba.

4) Hasil penentuan harga jual produk menggunakan metode cost plus pricing menunjukkan bahwa terdapat perbedaan harga jual produk antara harga jual produk yang diperoleh dengan perhitungan harga pokok produksi dengan harga jual produk yang selama ini ditetapkan oleh UMKM.

\section{Keterbatasan} adalah:

Beberapa keterbatasan dalam penelitian ini

1) Hasil penelitian tidak dapat digeneralisasi secara umum karena penelitian yang dilakukan hanya pada 3 UMKM dendeng sapi di Banda Aceh.

2) Hasil penelitian mungkin akan berbeda jika dilakukan pada tahun-tahun berikutnya karena penelitian ini hanya dilakukan berdasarkan perolehan harga pokok produksi pada tahun 2017 saja.

3) Penelitian ini hanya difokuskan pada usaha yang belum menentukan harga pokok produksi serta harga jual produknya.

4) UMKM tidak melakukan pencatatan secara lengkap dalam hal penerimaan dan pembiayaan menjadi keterbatasan dalam akurasi data yang diperoleh dari penelitian ini mungkin tidak $100 \%$ akurat.

\section{Saran}

Berdasarkan hasil penelitian yang diperoleh serta keterbatasan penelitian ini,maka peneliti ingin memberikan beberapa saran sebagai berikut:

1) Para pelaku usaha sebaiknya membuat laporan harga pokok produksi secara sederhana, karena laporan harga pokok produksi memberikan gambaran dengan jelas dan pasti mengenai pembiayaan produksi.

2) Para pelaku usaha sebaiknya menetukan harga jual produk berdasarkan laporan harga pokok produksi. Hal ini bertujuan agar pelaku usaha mengetahui berapa harga jual produk yang tepat untuk menutupi semua biaya produksi.

3) Bagi peneliti selanjutnya diharapkan dapat memperluas ruang lingkup penelitian, seperti 
menambah jenis produk yang menjadi objek penelitian serta membandingkan usaha yang sudah membuat laporan harga pokok produksi sehingga hasil penelitian lebih beragam.

4) Pemerintah Daerah sebaiknya memberikan pembinaan kepada para pelaku usaha UMKM dendeng sapi di Banda Aceh mengenai bagaimana tata cara mengelola usaha yang baik dan benar termasuk membuat laporan harga pokok produksi serta menetapkan harga jual produk yang tepat.

\section{DAFTAR PUSTAKA}

Alexandri. (2008). Manajemen Keuangan Bisnis. Edisi 1. Bandung: Alfabeta.

Arly, R. L., \& Sondakh, J. J. (2014). Analisis Varians dalam Penerapana Biaya Standar sebagai Alat Pengendalian Biaya Produksi pada UD Berkat Anugrah Manado. Jurnal EMBA. Vol. 2, No. 3. ISSN: 2303-1174, 570-579.

Badem, A. C., Ergin, E., \& Drury, C. (2013). Is Standard Costing Still Used? Evidence from Turkish Automotive Industry. International Business Research; Vol. 6, No. 7; ISSN 19139004,E-ISSN 1913-9012, 79-90.

Bustami, B., \& Nurlela. (2013). Akuntansi Biaya. Edisi 4. Jakarta: Mitra Wacana.

Carter, W. K. (2009). Akuntansi Biaya. Jakarta: Salemba Empat.

Edison, \& Sapta, U. (2010). Pengaruh Biaya Standar Terhadap Pengendalian Biaya Produksi ( Studi Kasus PT. ITP, Tbk). Jurnal Ilmiah Ranggagading. Vol. 10, No. 2, 120-130.

Fahmi, I. (2014). Analisis Kinerja Keuangan: Panduan bagi Akademisi, Manajer, dan Investor untuk Menilai dan Menganalisis Bisnis dari Aspek Keuangan. Bandung: Alfabeta.

Garrison, R. H., W.Norren, E., \& Brewer, P. C. (2013). Akuntansi Manajerial. Jilid 2. Terjemahan. Jakarta: Salemba Empat.

Hansen, C. T., Datar, S. M., \& Foster, G. (2013). Akuntansi Manajerial. Edisi 8. Jakarta: Salemba Empat.

Harahap, N., \& Vera, D, K. (2008). Pengaruh Efisiensi Biaya Produksi Terhadap Laba Bersih. Jurnal Akuntansi FE USU. Vol. 20, No. 1, ISSN: 0852-1875, 1-9.
Horngren, C. T., Datar, M., \& Foster, G. (2008). Akuntansi Biaya, Penekanan Manajerial. Jakarta: Erlangga.

Kasmir. (2012). Analisis Laporan Keuangan. Jakarta: PT. Raja Grafindo Persada.

Layaman, \& Nurlatifah. (2016). Strategi Meningkatkan Produksi UMKM di Kabupaten Cirebon Melalui Efektivitas Persediaan Bahan Baku dan Modal Usaha. Jurnal AL-Mustashfa. Vol.4, No.2, 111-123.

Makridakis, S., Wheelwright, S., \& Gee, V. E. (2008). Forecasting: Methods and Applications. New York: Wiley.

Martusa, R., \& Nasa, L. A. (2012). Penerapan Biaya Standar Terhadap Pengendalian Biaya Produksi: Studi Kasus pada CV Sejahtera Bandung. Jurnal Ilmiah Akuntansi. NO. 07. ISSN: 20864159, 1-20.

Massie, N. I., Saerang, D. P., \& Tirayoh, V. Z. (2018). Analisis Pengendalian Biaya Produksi untuk Menilai Efisiensi da Efektivitas Biaya Produksi. Jurnal Riset Akuntansi Going Concern. Vol. 13, No. 3, 355-364.

Megawati, D. L., Saifi, M., \& A, Z. Z. (2016). Analisis Perhitungan Biaya Standar sebagai Salah Satu Pendukung Efisiensi Biaya Produksi (Studi pada Koperasi Serba USaha Brosem Batu pada Tahun 2015). Jurnal Administrasi Bisnis (JAB). Vol. 38, No. 1, 97-105.

Mulyadi. (2009). Akuntansi Biaya. Edisi 5. Yogyakarta: YKPN.

Mursyidi. (2010). Akuntansi Biaya: Conventional Costing, Just In Time, dan Activity Based Costing. Bandung: PT. Refika Aditama.

Palupi, T. A., Z.A, Z., \& NP., M. W. (2016). Analisis Biaya Standar untuk Mendukung Efisiensi Biaya Produksi Perusahaan (Studi pada Pabrik Gula Lestari, Patianrowo, Nganjuk). Jurnal Administrasi Bisnis (JAB), Vol. 36 No. 1, 80-85.

Pratiwi, J. (2013). Penerapan Biaya Standar dalam Pengendalian Biaya Produksi pada PT. Pertani (Persero) Cabang Sulawesi Utara. Jurnal EMBA. Vol. 1, No. 4. ISSN: 2303-1174, 16171626.

Raiborn, A. C., \& Kinney, M. R. (2011). Akuntansi Biaya: Dasar dan Perkembangan. Buku 1. Edisi 7. Terjemahan. Jakarta: Salemba Empat. 
Riyanto, B. (2010). dasar dasar pembelanjaan perusahaan, edisi 4. Yogyakarta: BPFE.

Samryn, L. M. (2012). Akuntansi Manajemen, Edisi Revisi. Jakarta: Kencana.

Sekaran, U., \& Bougie, R. (2013). Research Methods for Business: A Skill Building Approach. Sixth Edition. New York: Wiley.

Siregar, B., Suripto, B., Hapsoro, D., Lo, E. W., \& Biyanto, F. (2013). Akuntansi Manajemen. Jakarta: Salemba Empat.

Siregar, B., Suripto, B., Lo, E. W., Herowati, E., Kusumasari, L., \& Nurofik. (2016). Akuntansi Biaya. Edisi 2. Jakarta: Salemba Empat.

Subagyo, J. (2011). Metode Penelitian (Dalam Teori dan Praktik). Jakarta: Rineka Cipta.

Sugiyono. (2014). Metode Penelitian Kuantitatif, Kualitatif, dan $R \& D$. Bandung: Alfabeta.

Sulaiman, M., Ahmad, N. N., \& Alwi, N. M. (2005). Is standard costing obsolete? Empirical evidence from Malaysia. Managerial Auditing Journal, Vol. 20 Iss 2, 109-124.

Syahril, \& Hasanuddin. (2017). Implementasi Teknologi Software As A Service (SAAS) Untuk Menentukan Harga Pokok Produksi Aktual Menggunakan Metode Biaya Standar Pada UMKM Kota Pekanbaru. Prosiding CELSciTech, vol 2. ISSN: 2541-3023 (pp. 93100). Pekanbaru: CELSciTech.

Taqwim, M. A., \& Haryono. (2015). Upaya Peningkatan Profitabilitas Produksi dengan Menggunakan Metode Penentuan Biaya Standar. Jurnal LIPI. Vol. 5, No. 2. ISSN: 20884591, 6-13.

Tompodung, O. (2014). Analisis Net Profit Margin pada Usaha Laundry di Kota Manado. Jurnal EMBA; Vol.2, No.2; ISSN 2303-1174, 16821690.

Undang Undang Republik Indonesia Nomor 20 Tahun 2008 Tentang Usaha Mikro Kecil dan Menengah (UMKM)

Peraturan Gubernur Aceh Nomor 72 Tahun 2016

www.depkop.go.id (diakses pada tanggal 3 Mei 2018)

www.diskop.acehprov.go.id (diakses pada tanggal 11 Mei 2018)

www.mediaaceh.com (diakses pada tanggal 13 Oktober 2018)

www.bukalapak.com (diakses pada tanggal 13 https://hargapangan.id (diakses pada tanggal 13 Oktober 2018) 